\title{
Minimum Parental Allowance Payments Received by Finnish Mothers
}

\author{
PENTTI TAKALA, Lic.Pol.Sc., Senior Researcher \\ HELKA HYTTI, Ph.D., Senior Researcher \\ The Social Insurance Institution, Helsinki, Finland
}

\begin{abstract}
In Finland, the number and the proportion of women receiving minimum maternity or parental allowance increased dramatically in the 1990s. Their share increased to a high point of 30 percent in 1996 and remained at over 25 percent to the end of the decade. The aim of this study was to describe some of the characteristics typical of these women, and to analyse how often and in what circumstances they had to rely on last-resort income support (social assistance and housing allowance). The material comprises data on the total working-aged population, retrieved from the income security registers maintained by the Social Insurance Institution and from the social assistance register maintained by Stakes (National Research and Development Centre for Welfare and Health). Both cross sectional and longitudinal data were analysed by means of cross tabulations and means as well as logistic regression. We could differentiate two groups of mothers receiving minimum benefit: young mothers and middle-aged mothers with many children. Twenty percent of women on the minimum allowance also received social assistance and 38 percent received housing allowance. Reliance on social assistance was particularly common among mothers who had delivered their first baby and among young mothers who had delivered more than one baby.
\end{abstract}

Keywords: Family benefit, minimum parental allowance, social assistance, housing allowance

\section{Introduction}

Finland's residence-based subsistence security system has so far kept pace with international standards of social provision. During the 1990s, however, certain minimum benefits lagged behind general economic development, leading to a decrease in their real value. At the same time, the need for income security remains high due to widespread unemployment. Unemployment, together with a combination of cuts in social welfare benefits, has increased reliance on last-resort income support (social assistance). (Sosiaalimenojen kehitys ... 2002, 124.)

Also during the 1990s, poverty increased in population groups most vulnerable to risks of income security. Although, in general, the poverty rate in Finland is still very 
low, poverty has increased since the 1990s. Studies have shown that the rate of child poverty doubled over the second half of the decade and poverty risk increased especially among the families with small children (Sauli et al. 2004). Cuts in minimum family benefits and a decrease in their real value have been proposed as reasons for this unfavorable development. Besides the minimum parental allowance, minimum family benefits also include the child home care allowance, which is an alternative to the use of public day care services.

Public debate on the minimum family benefits has focused also on their appropriate structure and level, which were addressed in a government report on the future (Finland for people ... 2004). The report outlined goals for turning social security and family policy in a direction that would allow parents to start a family sooner and make them better able to choose the number of children they wish to have. This would require changes in the minimum family benefits, which are available independent of family income. Otherwise, the possibilities of young and low-income parents, such as students nearing the end of their formal education, to have more children would be limited.

According to the programme of the current Finnish government, means-tested minimum income security is to be strengthened to ensure that the minimum benefits, when combined with housing allowances and general family benefits, provide a reasonable income without the need to resort to income support. It is essential from the point of view of social policy to secure the real value of minimum benefits and their adaptability to changes in the general standard of living over time. Adjustments in the level of minimum benefits can also ensure a reasonable level of consumption even when people are forced to depend on these benefits for a longer period of time. (See also Sosiaalimenojen kehitys ... 2002, 124.)

In this article, we concentrate on the receipt of minimum parental allowance by women, which underwent a dramatic increase during the 1990s. Of the minimum family benefits, the minimum parental allowance has also been shown to be more problematic than the child home care allowance, which is reflected in the fact that recipients of minimum parental allowance are more likely to have to rely on social assistance than recipients of home care allowance (Hiilamo et al. 2005).

The minimum parental allowance is a problem mainly for women. In 2003, one in five women on parental leave received parental allowance at the minimum rate, compared to just three percent of men. Men's share of all days paid at the minimum rate was under one percent. Even though in the mid-1990s nearly seven percent of men on parental leave were paid at the minimum rate, their share of all days paid at the minimum rate was then as it is now. Therefore, there is good reason to focus this article exclusively on women. 


\section{Development of the minimum parental allowance}

In Finland, as in the other Nordic countries, loss of income in connection with childbirth is compensated during the last few weeks prior to and the first months following childbirth. The benefit payable - maternity and parental allowance - is based on previous earnings. Also, in all Nordic countries except Denmark, people who are not active in the labor market qualify for a minimum parental allowance ${ }^{1}$. In Finland, the minimum allowance is payable to recipients with no or low income. The earnings-related parental allowance is equal to 70 percent of annual earnings up to $26,124 €$. On earnings exceeding this limit, the allowance will be less than 70 percent of earnings. There is no ceiling on the amount that may be awarded.

The proportion of women receiving minimum maternity or parental allowances increased dramatically in the 1990s. Until 1993, only five or six percent of parental allowances were awarded at the minimum rate. From 1994 on, this share increased to a high point of 30 percent in 1996 and remained at over 25 percent to the end of the decade. Different reasons have been presented for the change, including the finding that unemployment and fixed-term employment relationships became more common among women (Keinänen et al. 1999). It has also been argued that child home care allowances have increased the use of minimum per diem allowances. Recipients of minimum per diem allowances include women who have, after the birth of their previous child and before a new pregnancy, remained at home to care for their child while drawing child home care allowance. In such cases, the benefits for any subsequent maternity and parental leave are not based on earned income (Hiilamo 2002a, 253).

These explanations tell only part of the story. The increase in minimum parental allowances received by women is also due to changes in the criteria used to calculate the allowances. Figure 1 shows the days on minimum allowance as a proportion of the total number of days covered, and the recipients with no income as a proportion of the total number of women receiving parental allowance. Originally, only persons with no income qualified for the minimum parental allowance, and earning-related allowances were accumulated on the top of the minimum allowance. In 1994 and 1995, there were more women on the minimum allowance because the amount of allowance was determined by reference to the basic amount of the home care allowance. This implies that some low-income persons no longer received any earnings-based allowance but rather were paid parental allowance at the minimum rate. However, some of them received less money before 1994 in earnings-related benefits than what was payable as the minimum allowance in 1994 and 1995. In 1996, the system was again changed, the income limit to qualify for the minimum allowance being nearly doubled

\footnotetext{
${ }^{1}$ Unlike in the other Nordic countries, in Norway, the benefit (maternity grant) is a one-time payment.
} 
(from $2,215 €$ to $4,324 €$ ), and the minimum allowance being reduced considerably (from 13,35 € per diem to 10,09 € per diem). It was again fixed at the rate of the basic home care allowance - now significantly lower than before. As seen in Figure 1, the proportion of women with no income increased by only 10 percentage points from 1993 to 1996 while the proportion of women on minimum allowance rose by 23 percentage points over the same period.

Figure 1. Minimum parental allowance payments received by mothers, 1990-2004 (\%).

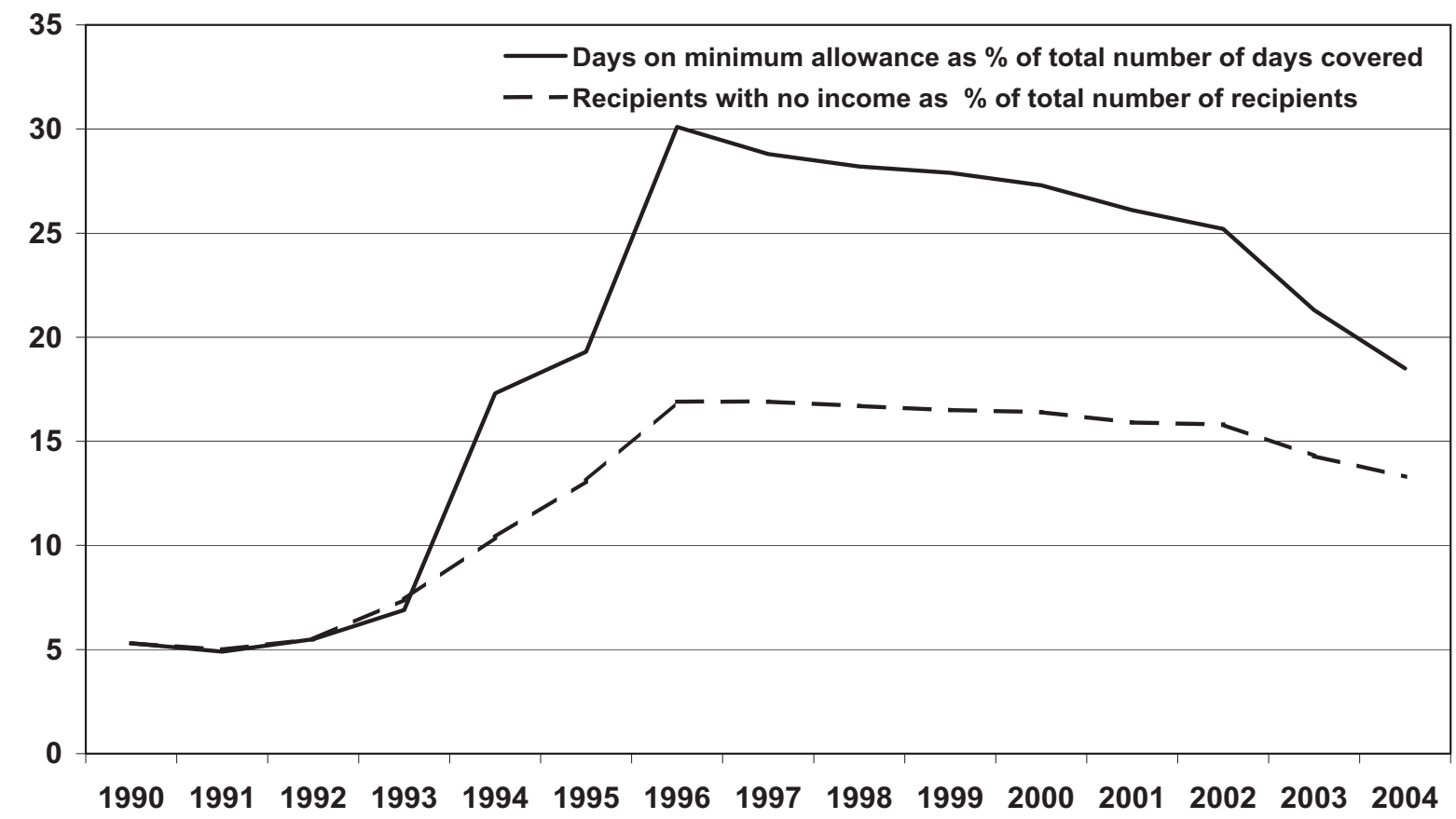

Source: Statistics of the Social Insurance Institution

These changes meant that in terms of the value of benefits, low-income persons fared worse than other recipients of parental allowance because their low income no longer guaranteed them any earnings-related allowance. Moreover, the gap between the real values of the minimum allowance and the earnings-related allowance began to open up due to the minimum allowance not being adjusted for changes in the cost-of-living index. From January 1995 to December 2002, the gross value of the minimum parental allowance decreased by as much as 34.4 percent (Hiilamo 2002b, 219).

Until now, the recipients of the minimum parental allowance have been understudied. What is known is that women on minimum allowance differ from women on earningsbased allowance in terms of educational attainment and age. Fifty-seven percent of mothers under 25 years of age, compared with 22 percent of older mothers, receive minimum parental allowance (Sosiaalimenojen kehitys ... 2002, 126). According to one survey, 60 percent of women with primary and secondary school qualification 
received minimum parental allowance, while only 15 percent of women with a university degree did so (Takala 2000,34). One purpose of this article is to attempt to fill this gap in knowledge.

\section{Aim and material}

The aim of this study is to describe some of the characteristics typical of women receiving minimum parental allowance in contrast to women on earnings-related parental allowance. We also analyse how often and in what circumstances this minimum benefit fails to provide the recipients and their households with a necessary subsistence, forcing them to rely on last-resort income support. We will attempt to discover the degree of overlap between the minimum allowance, social assistance and housing allowance, and determine the effect of the duration of minimum allowance receipt on the need for last-resort income support. After an analysis of the research data, a review of the development of the minimum parental allowance and of the numbers of recipients after the research period will be presented.

The material comprises data on the total working-aged population $(\mathrm{N}=3,453,842)$, retrieved from the income security registers maintained by the Social Insurance Institution and from the social assistance register maintained by Stakes (National Research and Development Centre for Welfare and Health). The unit of analysis is the individual recipient. Cross sectional data about the use of benefits as of 30 November 2000 and longitudinal data about the duration of benefits from 1997 to 2000 were compiled.

The data on social assistance and housing allowance were organized by households. In our data, this was converted to individual-level characteristics, and so the data on household structure have been changed to background information describing an individual. The data also include other demographic information and details about eligibility factors available in the Social Insurance Institution's registers. However, socio-economic background information was not available.

\section{Results}

According to our data, maternity and parental allowances were paid to 47,100 women in November 2000. Of these women, 34,000 received earning-related parental allowance and 13,100 minimum parental allowance. This means that the proportion of women on the minimum allowance was 27.9 percent. This is about the same figure as the proportion of minimum allowance days of total days covered in 2000, namely 27.3 percent (Statistical Yearbook ... 2002, 132).

Age was clearly linked to the probability to receive parental allowance at the minimum rate (Figure 2). Ninety percent of women under 20 years of age received the minimum allowance. After age 20, the proportion of women who received the earning-related 
allowance increased rapidly with age. The midpoint was at age 22, after which more women received earnings-related allowance than received minimum allowance. The proportion of women on minimum allowance decreased up to the age of 29 years, and thereafter remained at 20 percent. The median ages of women receiving minimum allowance and those receiving earnings-related allowance were 27 and 31 years, respectively.

Figure 2. The number of women receiving parental allowances, by age of recipient, in November, 2000.

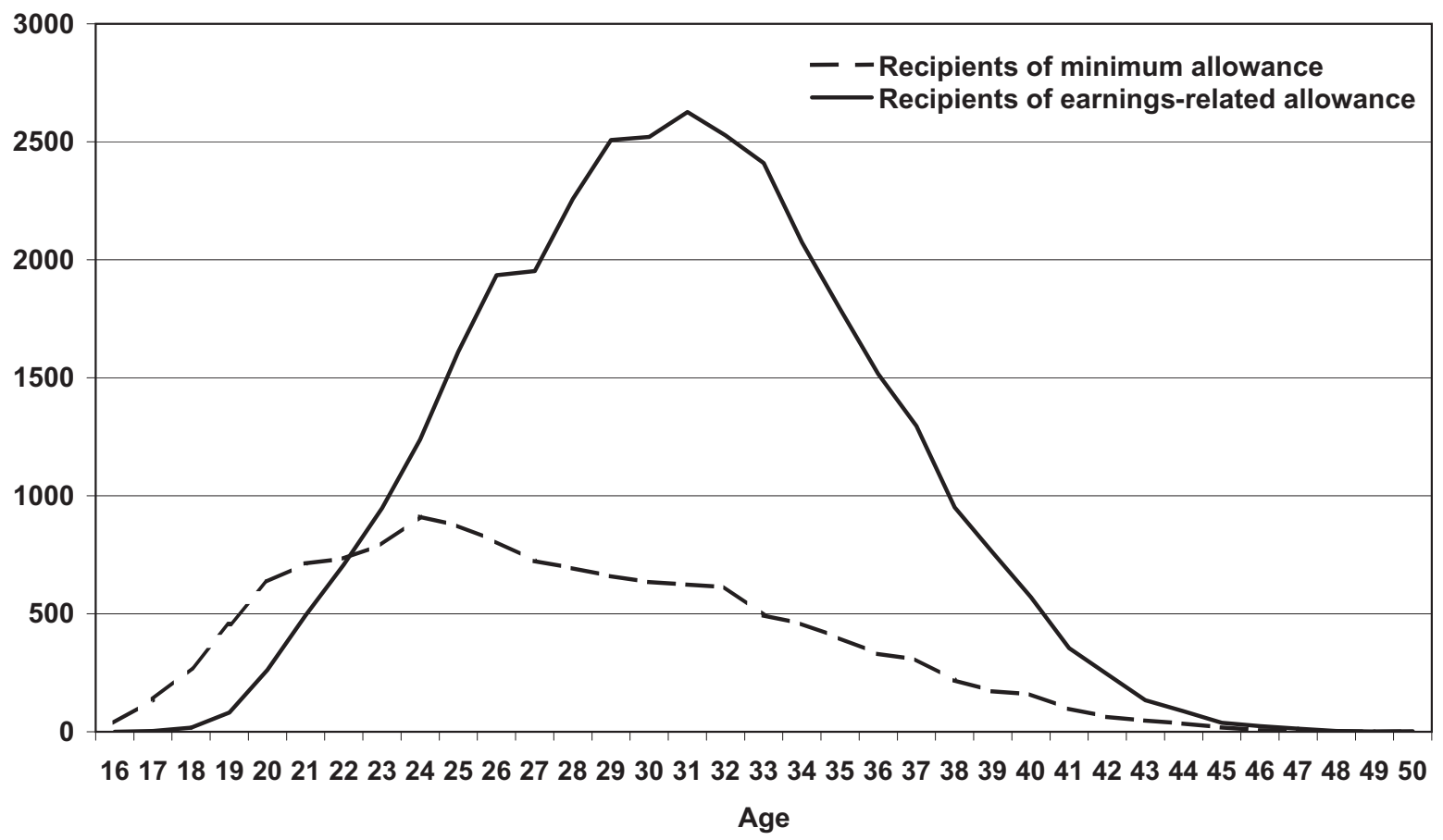

The number of children, too, was linked to the probability to receive the minimum allowance. Twenty-four percent of women with one or two children received the parental allowance at the minimum rate, compared to one third of women with three children, nearly half of women with four children and more than 60 percent among women with five or more children.

The probability to receive the minimum allowance increased along with the number of children regardless of the mother's age, but less dramatically in the older age groups. For example, 82 percent of women under 25 years of age with three children received parental allowance at the minimum rate, while the proportions among women aged 25-29 years and over 30 years were 52 and 23 percent, respectively. Younger women were less likely to have been employed for the requisite six months, and therefore, more likely to be on the minimum allowance. The more births a women had delivered, the more often they had been outside the labor market even at older ages, and therefore, the more often they were on the minimum allowance. 
Our data allowed us to identify which other benefits mothers had received before the parental leave. These preceding benefits could shed light on the reasons behind their receipt of parental allowance at the minimum rate. Figures from the year 2000 showed that prior to receiving minimum parental allowance, mothers had most often received child home care allowance (over 50 percent of mothers on the minimum allowance), means-tested labor market subsidy (20 percent) or study grant (nearly 20 percent) ${ }^{2}$. These were the most important reasons for not having income and thus ending up on the minimum allowance. However, the reasons varied considerably according to the number of children. When a mother only had one new-born child, the chief reasons were studying (one third of mothers on the minimum allowance) and unemployment (also one third). Starting from the second child, the most important reason by far was the desire to take a child care leave (about 80 percent), while unemployment (10-15 percent) and studying (3-10 percent) played a much smaller role.

How well did the minimum parental allowance meet the recipients' financial needs? How many women had to supplement their minimum benefits with last-resort income support? Our data showed that there was a surprisingly large overlap between social assistance, housing allowance and minimum allowance. In November 2000, 20.4 percent of women on the minimum allowance received social assistance and 37.8 percent received housing allowance.

Who received social assistance? Table 1 (on next page) shows that mothers with one child had the highest proportion of social assistance recipients regardless of mother's age. Among mothers under 25 years of age and on the minimum parental allowance, social assistance was received by 33 percent of mothers who had delivered their first baby, and by 23-24 percent of mothers who had delivered their second or third baby. Among mothers 25 years of age or over, about one in five primiparas on minimum parental allowance received social assistance, compared to 10-16 percent of other mothers of the same age on the minimum allowance. A corresponding analysis was performed on the simultaneous receipt of social assistance and housing allowance among mothers on the minimum allowance according to the age of the mother and the number of children. No clear relationships between these variables were observed.

\footnotetext{
${ }^{2}$ Ulla Hämäläinen (2004, 59-60) presents rather similar results: in 1996, 43 percent of women receiving minimum parental allowance had received a family benefit (mostly home care allowance) in the preceding year, while one third had received benefits for students and 18 percent unemployment benefits.
} 
Table 1. Recipients of social assistance as a percentage of women receiving the minimum parental allowance, by age of recipient and number of children (number of recipients in brackets).

\begin{tabular}{|c|c|c|c|c|c|c|c|c|c|c|}
\hline \multirow[b]{2}{*}{ Age } & \multicolumn{10}{|c|}{ Number of children } \\
\hline & 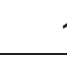 & 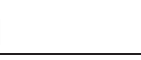 & & 2 & & 3 & & 4 & & $5+$ \\
\hline Under 25 & 33 & $(2,586)$ & 24 & $(1,155)$ & 23 & (278) & 19 & (52) & 0 & (7) \\
\hline $25-34$ & 19 & $(1,040)$ & 14 & $(1,351)$ & 14 & (712) & 15 & (289) & 10 & (212) \\
\hline $35+$ & 21 & (629) & 14 & $(1,340)$ & 14 & $(1,111)$ & 16 & (569) & 11 & (908) \\
\hline
\end{tabular}

Next, we considered the overlapping of social assistance and housing allowance with minimum parental allowance (in 2000) according to the duration of parental allowance in 1997-2000 (Figure 3). On the horizontal axis, recipients of minimum parental allowance are grouped according to how long the allowance was paid during the two and half years preceding the research period. The number of persons belonging to each group is shown above the columns. On the vertical axis we see the proportion of those receiving not only minimum parental allowance but also social assistance, housing allowance or both.

We can see that the effect of the duration of minimum parental allowance on the probability to receive social assistance is different from its effect on the probability to receive housing allowance. The shorter the period on minimum parental allowance, the more likely the women were to have received social assistance. With the housing allowance, the reverse was true. The longer the women had received parental allowance the more likely they were to have received housing allowance. Interpreting the result, we have to remember that the women who had been on parental allowance for over a year had given birth to at least two children during the research period, and therefore, this group differs from those who delivered only one child. Among those who had received parental allowance for a brief time only, there are many young and low-income families. We may assume that where parental allowance has been paid for several successive births, the family's financial situation may be better. The finding that the receipt of housing allowance becomes more widespread the longer the period on parental allowance may be explained by bigger family size. 
Figure 3. Overlapping of social assistance and housing allowance among women on the minimum parental allowance by duration of benefit, 30 November 2000 (\%).* The number of allowance recipients in thousands is shown above the columns.

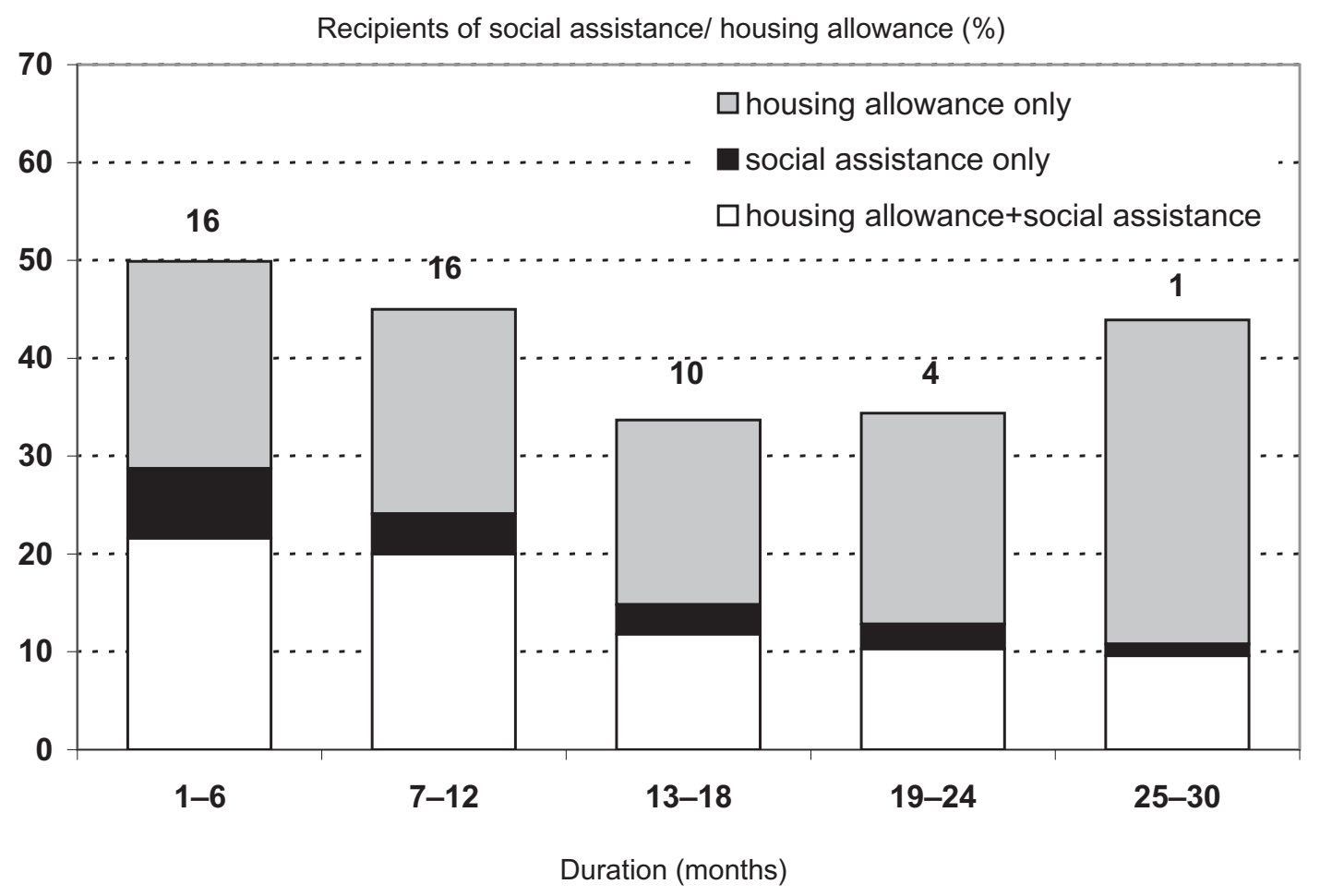

* Combined duration of minimum parental allowance, during 1997-2000.

Finally, we considered the relationships between social assistance and a number of background variables as logistic regressions among women on the minimum parental allowance (Table 2). This analysis allowed us to identify the independent effects of different variables on the receipt of social assistance and on the simultaneous receipt of social assistance and housing allowance. Women receiving maternity or parental allowance at the minimum rate were distributed rather evenly by age. One third were under 25 years of age and 38 percent over 35 . Young mothers were particularly likely to have to rely on the last-resort income support. Their odds ratio - showing the need for social assistance - was nearly double compared to the older age groups. The odds ratio for the simultaneous receipt of social assistance and housing allowance tripled from the oldest to the youngest age group. 
Table 2. Overlapping of social assistance and social assistance paid alongside housing allowance among women who received minimum parental allowance in 2000 (odds ratios, logistic regression).

\begin{tabular}{|c|c|c|c|c|c|c|c|}
\hline & \multirow[t]{2}{*}{ Number } & \multicolumn{3}{|c|}{ Social assistance } & \multicolumn{3}{|c|}{$\begin{array}{l}\text { Social assistance } \\
\text { alongside housing } \\
\text { allowance }\end{array}$} \\
\hline & & $\begin{array}{c}\text { Model } \\
\mathrm{I}\end{array}$ & $\begin{array}{c}\text { Model } \\
\text { II }\end{array}$ & $\begin{array}{c}\text { Model } \\
\text { III }\end{array}$ & $\begin{array}{l}\text { Model } \\
\text { IV }\end{array}$ & $\begin{array}{l}\text { Model } \\
\mathrm{V}\end{array}$ & $\begin{array}{l}\text { Model } \\
\text { VI }\end{array}$ \\
\hline \multicolumn{8}{|l|}{ Age (years) } \\
\hline $\begin{array}{l}\text { - under } 25 \\
-25-34 \\
-35+\end{array}$ & $\begin{array}{l}4,100 \\
3,600 \\
4,600\end{array}$ & $\begin{array}{l}1.00 \\
0.52 \\
0.52\end{array}$ & $\begin{array}{l}1.00 \\
0.51 \\
0.46\end{array}$ & $\begin{array}{l}1.00 \\
0.54 \\
0.51\end{array}$ & $\begin{array}{l}1.00 \\
0.41 \\
0.34\end{array}$ & $\begin{array}{l}1.00 \\
0.40 \\
0.31\end{array}$ & $\begin{array}{l}1.00 \\
0.42 \\
0.34\end{array}$ \\
\hline \multicolumn{8}{|l|}{ Number of children } \\
\hline $\begin{array}{l}-1 \\
-2-3 \\
-4+\end{array}$ & $\begin{array}{l}4,300 \\
5,900 \\
2,000\end{array}$ & $\begin{array}{l}1.00 \\
0.68 \\
0.70\end{array}$ & $\begin{array}{c}1.00 \\
(1.02) \\
(1.19)\end{array}$ & $\begin{array}{c}1.00 \\
(0.94) \\
(1.08)\end{array}$ & $\begin{array}{l}1.00 \\
0.84 \\
2.77\end{array}$ & $\begin{array}{l}1.00 \\
1.25 \\
4.32\end{array}$ & $\begin{array}{c}1.00 \\
(1.11) \\
3.91\end{array}$ \\
\hline \multicolumn{8}{|l|}{ Family form } \\
\hline $\begin{array}{l}\text { - two parents } \\
\text { - single parent }\end{array}$ & $\begin{array}{r}11,000 \\
1,200\end{array}$ & $\begin{array}{l}1.00 \\
7.84\end{array}$ & $\begin{array}{l}1.00 \\
7.41\end{array}$ & $\begin{array}{l}1.00 \\
7.59\end{array}$ & $\begin{array}{r}1.00 \\
19.29\end{array}$ & $\begin{array}{r}1.00 \\
18.28\end{array}$ & $\begin{array}{r}1.00 \\
18.67\end{array}$ \\
\hline \multicolumn{8}{|l|}{ Area of residence } \\
\hline $\begin{array}{l}\text { - capital area } \\
\text { - other big cities } \\
\text { - other municipalities }\end{array}$ & $\begin{array}{l}2,000 \\
3,700 \\
6,600\end{array}$ & $\begin{array}{c}1.00 \\
(1.07) \\
0.73\end{array}$ & $\begin{array}{c}1.00 \\
(1.06) \\
0.73\end{array}$ & $\begin{array}{c}1.00 \\
(1.05) \\
0.74\end{array}$ & $\begin{array}{l}1.00 \\
0.82 \\
0.43\end{array}$ & $\begin{array}{l}1.00 \\
0.82 \\
0.43\end{array}$ & $\begin{array}{l}1.00 \\
0.81 \\
0.44\end{array}$ \\
\hline \multicolumn{8}{|c|}{$\begin{array}{l}\text { Duration of parental leave within } \\
4 \text {-year period (months) }\end{array}$} \\
\hline $\begin{array}{l}\text { - under } 6 \\
-6-12 \\
-13-24 \\
-25+\end{array}$ & $\begin{array}{r}1,800 \\
4,400 \\
5,200 \\
800\end{array}$ & & $\begin{array}{l}1.00 \\
0.85 \\
0.54 \\
0.37\end{array}$ & & & $\begin{array}{c}1.00 \\
(0.90) \\
0.54 \\
0.64\end{array}$ & \\
\hline \multicolumn{8}{|c|}{$\begin{array}{l}\text { Duration of child home care al- } \\
\text { lowance within 4-year period } \\
\text { (months) }\end{array}$} \\
\hline $\begin{array}{l}\text { - under } 6 \\
-6-12 \\
-13-24 \\
-25+ \\
\end{array}$ & $\begin{array}{l}4,600 \\
1,000 \\
2,200 \\
4,500 \\
\end{array}$ & & & $\begin{array}{c}1.00 \\
(0.83) \\
0.69 \\
0.57 \\
\end{array}$ & & & $\begin{array}{l}1.00 \\
0.84 \\
0.66 \\
0.65 \\
\end{array}$ \\
\hline
\end{tabular}

* Figures in parentheses are not statistically significant $(p<0.05)$.

The risk of having to supplement the minimum benefit with last-resort income support was especially high among single parents. However, it must be noted that this group was small (1,200 persons) compared to recipients of the minimum benefit in two-parent households $(11,000)$.

When we added the duration of parental leaves and child care leaves (on home care allowance) into the models, the picture changed a little bit due to the number of children. However, we have to remember that women who had received parental allowance for over a year had given birth to at least two children during the last four years. As Table 2 shows, the connection between the number of children and receiving social assistance 
disappeared when the durations of family benefits (minimum parental allowance and home care allowance) were adjusted by turns. However, the risk to receive social assistance diminished in relation to how long family benefits had been paid to the mother during the last four years. Therefore, we can argue that the negative relationship between the number of children and the need for social assistance - presented in Table 1 - among women on minimum allowance still remains, but this effect is now seen only in duration variables due to the strong correlation of explaining variables.

\section{Recent developments}

Following the period represented by our material, a number of reforms of the minimum parental allowance provisions have been implemented. At the beginning of 2003, the amount of the minimum payment was increased from $252.25 €$ per month to $286.25 €$ per month, and the annual income limit to 4,906 €. This reform also made it possible to calculate the amount of parental allowance due by reference to the amount of a preceding unemployment allowance. This meant that the large number of women who earlier would have received the parental allowance at the minimum rate now qualified for a higher allowance. The proportion of mothers on the minimum allowances dropped remarkably from 25.2 percent in 2002 to 21.3 percent in 2003 and to 18.5 percent in 2004 (Figure 1). The decrease in the number of women with no income was less dramatic (2.5 percentage points from 2002 to 2004).

In the beginning of 2005, the amount of the minimum benefit was increased again, this time more noticeably, to $380.00 €$ per month, which amount is payable to lowincome individuals with annual earnings of less than $6,513 €$. This was a relatively big improvement, and together with the increase that preceded it meant that the amount of the minimum allowance increased by 40.5 percent in real value between 2000 and 2005 (Hiilamo et al. 2005, 32). While this increase is a positive development, it must also be recognized that the number and proportion of mothers on the minimum allowance is again edging upward. During the first three months of 2005, the proportion was 19.6 percent.

The uprating of the minimum benefit allowed Finland to keep pace with the other Nordic countries. In Norway, the benefit comparable to our minimum parental allowance is the maternity grant. It is paid for the non active ${ }^{3}$ as a lump sum of 33,584 NOK $(4,090 €)$ (MISSOC 2004, 421). If we multiply the amount of the daily amount of the Finnish minimum parental allowance $(15,20 €)$ by the number of days of maternity and parental leave mothers are entitled to, we get almost the same value (3,998 €). However, the benefit is subject to taxation in Finland but not in Norway.

\footnotetext{
${ }^{3}$ Moreover, in Norway, if the parental benefit for the full period should be lower than the maternity grant, the parental benefit will be topped up with the differential.
} 
Traditionally, the amount of the minimum parental allowance has been higher in Finland than in Sweden. Heikki Hiilamo (2002a, 253) has made calculations based on a cost-of-living index comparison about the real minimum pre-tax value of parental allowance in both countries. The results are expressed as 1999 USD purchasing power parities per month. The analysis shows that the minimum per diem allowances remained higher in Finland than in Sweden throughout the 1990s. However, this is no longer the case. The minimum guaranteed benefit (grundbelopp) was increased to $20 €$ (180 SEK) per day in 2004 (MISSOC 2004, 703), which is more than 30 percent higher than the minimum daily amount in Finland. In Denmark, there is no minimum parental allowance.

In a forthcoming reform, which will become effective in October 2005, the calculation criteria of the Finnish parental allowances will be changed so that an entitlement to earnings-related allowance is retained if a new child is born within three years of the previous birth. This will probably decrease the number of women on the minimum allowance. It will be interesting to see how large the effect is going to be. In Sweden, a similar reform was carried out as early as in 1980, when a 'speed premium' on childbearing was introduced to allow parents to retain the parental benefits due to them until the next birth if it arrived within two years (in 1986 extended to thirty months). For longer birth intervals, benefit rights must be re-established by earning a work-related income. During the 1980s - a period of a general rise in fertility in Sweden - parents reacted by increasing their fertility particularly strongly before the end of the eligibility interval (Hoem 1993; Hoem and Hoem 1996). However, the 'speed premium' had an effect mainly on the timing of births, and its effect on fertility disappeared in the 1990s without any changes being made to the determination criteria (Hiilamo 2002a, 247).

\section{Summary}

The results of this study indicate a clear need for social assistance and housing allowance among the women receiving minimum parental allowance. In the research period, minimum maternity or parental allowance was paid to 13,100 women, most of them young mothers. Sixty-four percent of the women on minimum allowance were under 30 years of age and 36 percent of them were under 25 . Also the number of children was linked to receiving parental allowance at the minimum rate. The more children they had, the more likely women were to be on the minimum benefit - regardless of their age. We can differentiate two groups of mothers receiving minimum benefit: young mothers and middle-aged mothers with many children.

Twenty percent of all women on the minimum allowance received also social assistance and 38 percent received housing allowance. Reliance on social assistance was particularly common among mothers who had delivered their first baby and among young mothers who had delivered more than one baby. Women over 25 years of age 
with two or three children had less need for social assistance. The result confirms the hypothesis that problems of income security or financial instability can be a considerable obstacle to lowering the age of primaparas and generally making it possible to start a family earlier than is now the case.

The reforms implemented after the research period and those yet to be implemented in 2005 will improve the financial position of people receiving minimum family benefits over the situation shown in this study. Their financial well-being has improved due to the increase of the minimum parental allowance. Moreover, the proportion of women receiving parental allowance at the minimum rate has already decreased (because of the linkage with the rate of the preceding unemployment allowance). It will probably decrease more after October 2005 once the right to earnings-related allowance can be retained if a new child is born within three years of the previous one. These reforms will probably decrease the need for last-resort income support and clearly also serve the family policy goal of allowing parents to choose to have their first child earlier.

\section{References}

Finland for people of all ages. Government report on the future: demographic trends, population policy, and preparation for changes in the age structure. Helsinki: Prime Minister's Office, Publications 34/2004.

Hiilamo, H. 2002a. The rise and fall of Nordic family policy? Historical development and changes during the 1990s in Sweden and Finland. Stakes research report 125. Helsinki: Stakes (the National Research and Development Centre for Welfare and Health).

Hiilamo, H. 2002b. Perheiden taloudellinen tukeminen [Financial support of families]. In: Suomalaisten hyvinvointi 2002 [Welfare in Finland 2002], edited by M. Heikkilä and M. Kautto, pp. 214-228. Helsinki: Stakes.

Hiilamo, H., H. Hytti, and P. Takala. 2005. Työikäiset toimeentuloturvan vähimmäisetuuksien saajina [Working-aged as recipients of minimum benefits]. Helsinki: Kela, sosiaali- ja terveysturvan selosteita 42/2005.

Hoem, J.M. 1993. Public policy as the fuel of fertility: Effects of a policy reform on the pace of childbearing in Sweden in the 1980s. Acta Sociologica 36(1):19-31.

Hoem, B. and J.M. Hoem. 1996. Sweden's family policies and roller-coaster fertility. Journal of Population Problems (Tokyo) 52(3-4):1-22.

Hämäläinen, U. 2004. Nuorten tulojen ja toimeentulon palapeli [The income and subsistence puzzle faced by young people]. Eläketurvakeskuksen tutkimuksia 2004:1.

Keinänen, P, L. Savola, and H. Sauli. 1999. Suhdanteet, sosiaalipolitiikka ja naisen paikka [Economic trends, social policy and the woman's place]. Hyvinvointikatsaus 3/1999, pp. 34-36.

MISSOC 2004: Social protection in the member states of the European Union, of the European Economic Area and in Switzerland. Situation on 1 May 2004. European Commission, Employment and social affairs, 2005.

Sauli, H, M. Bardy, and M. Salmi. 2004. Families with small children face deteriorating circumstances. In: Welfare in Finland, edited by M. Heikkilä and M. Kautto, pp. 20-37. Helsinki: Stakes. 
Sosiaalimenojen kehitys pitkällä aikavälillä. SOMERA-toimikunnan taustaraportti [Development of social costs in the long run. Background report of the SOMERA Committee]. Helsinki: Sosiaali- ja terveysministeriö, julkaisuja 2002: 21, 2002.

Statistical Yearbook of the Social Insurance Institution, Finland 2000. A Publication by the Social Insurance Institution T1:36, 2001.

Takala, P. 2000. Lastenhoito ja sen julkinen tuki [Childcare and public support for it]. Helsinki: Stakes, tutkimuksia 110. 